\title{
DAMPAK KEGIATAN EKSTRAKURIKULER TERHADAP PEMBENTUKKAN KARAKTER SISWA SMA NEGERI 1 BRANDAN BARAT
}

\author{
${ }^{1}$ Lilis Saputri, ${ }^{2}$ Djaka Setya Syaputra \\ 1'falinsyah16@gmail.com, ${ }^{2}$ setyadjaka1905@gmail.com
}

\begin{abstract}
ABSTRAK
Jenis penelitian ini adalah penelitian deskriptif kuantitatif. Tujuan penelitian ini adalah untuk mengetahui dampak kegiatan ekstrakurikuler terhadap pembentukkan karakter siswa SMA Negeri 1 Brandan Barat. Populasi dalam penelitian ini adalah siswa SMA Negeri 1 Brandan Barat. Sampel dalam penelitian ini adalah sebanyak 30 orang sampel dari anggota aktif yang tergabung dalam unit kegiatan ekstrakurikuler SMA Negeri 1 Brandan Barat. Berdasarkan hasil penelitian dan analisis data diperoleh setiap indikator pada angket pembentukkan karakter siswa di SMA Negeri 1 Brandan Barat diperoleh Trustworthiness sebesar 84,58 \% kategori baik, Fairness sebesar 96,98\% kategori sangat baik, Carring sebesar 85,20\% kategori sangat baik, Respect sebesar 84,06\% kategori baik, Citizenship sebesar 79,17\% kategori baik, Responsibility sebesar 83,57 \% kategori baik. Dapat disimpulkan bahwa setiap indikator untuk angket karakter siswa yang mengikuti ekstrakurikuler sangat baik. Hal ini memberikan dampak positif yang signifikan pada karakter siswa yang mengikuti ekstrakurikuler di SMA Negeri 1 Brandan Barat bahwa pada kegiatan ekstrakurikuler yang diikuti siswa akan membentuk karakter siswa SMA Negeri 1 Brandan Barat dilihat dari rata-rata persentase keseluruhan termasuk dalam kategori sangat tinggi.
\end{abstract}

Kata Kunci : Ekstrakurikuler, Karakter Siswa 


\section{PENDAHULUAN}

Fenomena yang terjadi di tengah masyarakat yakni meningkatnya kekerasan di kalangan remaja yang berakibat hilangnya masa depan, penggunaan bahasa dan kata-kata yang buruk, peningkatan perilaku merusak diri seperti penggunaan narkoba, alkohol, dan seks bebas, serta korupsi dan penggelapan yang terjadi, semakin kaburnya pedoman moral baik dan buruk, menurunnya etos kerja, semakin rendahnya rasa hormat kepada orangtua dan guru, serta menguatnya budaya ketidakjujuran. Dekadensi atau kemerosotan moral yang dialami masyarakat merupakan pertanda kemunduran dan kehancuran bangsa, sebaliknya moralitas merupakan faktor penting bagi pembangunan identitas dan karakter masyarakat suatu bangsa. Saputri (2018 : 181) menyatakan pendidikan merupakan faktor utama dalam pembentukan pribadi manusia, secara umum pendidikan memiliki arti sebagai suatu proses usaha dalam mengembangkan diri setiap individu untuk dapat hidup dan melangsungkan kehidupan, sehingga menjadi seorang yang terdidik.

Kegiatan ekstrakurikuler berarti kegiatan pendidikan yang dilakukan di luar jam pelajaran tatap muka. Kegiatan tersebut dilaksanakan di dalam dan/atau di luar lingkungan sekolah dalam rangka memperluas pengetahuan, meningkatkan keterampilan, dan menginternalisasi nilai-nilai atau aturan-aturan agama serta norma-norma sosial baik lokal, nasional, maupun global untuk membentuk insan yang paripurna. Dengan kata lain, ekstrakurikuler merupakan kegiatan pendidikan di luar jam pelajaran yang ditujukan untuk membantu perkembangan peserta didik, sesuai dengan kebutuhan, potensi, bakat, dan minat melalui kegiatan yang secara khusus diselenggarakan oleh pendidik atau tenaga kependidikan yang berkemampuan dan berwenangan di sekolah. Saputri (2020 : 50) menyatakan perbedaan tingkat percaya diri yang dimiliki individu tentu akan mempengaruhi perolehan prestasi belajar. Individu yang memiliki percaya diri yang tinggi akan memperoleh pretasi yang baik karena selalu beranggapan positif dan percaya terhadap kemampuan diri sendiri. Begitupun sebaliknya, individu yang memiliki percaya diri yang rendah akan memiliki prestasi belajar yang kurang memuaskan karena selalu beranggapan negatif dan tidak percaya akan kemampuan dan potensi yang dimilikinya.

Dalam ekstrakurikuler selain aspek kognitif, siswa juga belajar mengenai aspek afektif, yaitu hal-hal yang berkaitan dengan perilaku dan sikap. Dari segi afektif ini banya tujuan dan manfaat yang diharapkan dapat tercapai oleh siswa dalam mengikuti ekstrakurikuler, diantaranya sikap sportif, memiliki rasa tanggung jawab, adanya keinginan bekerja sama, cepat mengambil keputusan, menghargai lawan bermain, dan lain sebagainya. Kegiatan ekstrakurikuler juga dapat mempengaruhi perkembangan karakter seseorang. Karakter terasosiasikan dengan temperamen yang memberinya sebuah defenisi yang menekankan unsur psikososial yang dikaitkan dengan pendidikan dan konteks lingkungan. Karakter itu perlu dengan sengaja dibangun, dibentuk, ditempat, dan dikembangkan serta dimantapkan.

Dalam melakukan kegiatan ekstrakurikuler setiap siswa biasanya memiliki karekteristik perilaku yang berbeda-beda perilaku itu dapat terwujud apabila seseorang melakukan aktivitas sebagaimana dijelaskan oleh Hartasasmita (1985 : 10) bahwa "pengertian umum dari karakter dapat dikatakan hanyalah merupakan reaksi yang tertutup dan belum merupakan tindakan atau aktivitas dan reaksi yang terbuka yang terwujud dalam bentuk tindakan atau aktivitas". Mengacu pada uraian di atas maka reaksi hendaknya digunakan sebagai sarana untuk merangsang pertumbahan dan perkembangan jasmani, mental, emosional, dan sosial yang selaras dalam upaya mengembangkan kemampuan dasar, menanamkan kedisplinan, nilai, dan sikap positif, membiasakan hidup sehat serta dapat merubah perilaku siswa, perilaku pada dasarnya ditujukan untuk mencapai tujuan (Moekijat, 2002 : 14).

Hasil observasi yang peneliti pada siswa SMA Negeri 1 Brandan Barat diperoleh banyak masalah sosial sering dikaitkan dengan masalah 
perilaku menyimpang dan bahkan pelanggaran hukum atau tindak kejahatan. Permasalahan yang sering terjadi yaitu siswa seringkali melakukan perilaku agresi pasif (bolos sekolah), perilaku yang tidak dapat dikendalikan (menentang aturan disiplin sekolah, mencuri di kelas), perilaku agresi aktif (vandalisme/merusak tanpa alasan) serta cabut saat jam pelajaran, merokok, membawa senjata tajam, terlambat datang ke sekolah, tidak memakai atribut sekolah, berkata-kata kotor atau kasar, kurang sopan kepada teman atau guru, tidak mengerjakan tugas, tidak menaati perintah guru, melawan guru, individualis, saling bermusuhan antar teman bahkan sampai ada yang berkelahi dengan temannya sendiri. Optimalisasi kegiatan belajar mengajar yang masih minim dikarenakan kekurangan tenaga pengajar menjadi penyebab siswa terlihat terabaikan saat di kelas. Untuk itu siswa dituntut untuk mengikuti kegiatan ekstrakurikuler, melalui kegiatan ekstrakurikuler siswa diarahkan untuk memilih sesuai dengan minat, bakat, dan kemampuan siswa sehingga siswa akan bertambah pengayaan diri akan potensi yang dimilikinya.

Berdasarkan uraian diatas didapatkkan bahwa kegiatan ekstrakurikuler akan berdampak pada pembentukkan karakter siswa SMA Negeri 1 Brandan Barat.

\section{Ekstrakurikuler}

Prinsip-prinsip yang terkandung dalam kegiatan ekstrakurikuler adalah :

a. Individual, yaitu prinsip kegiatan ekstrakurikuler yang sesuai dengan potensi, bakat, dan minat peserta didik masing-masing

b. Pilihan, yaitu prinsip kegiatan ekstrakurikuler yang sesuai dengan keinginan dan diikuti secara sukarela peserta didik

c. Keterlibatan aktif, yaitu prinsip kegiatan ekstrakurikuler yang menuntut keikutsertaan peserta didik secara penuh

d. Menyenangkan, yaitu prinsip kegiatan ekstrakurikuler dalam suasana yang disukai dan menggembirakan peserta didik e. Etos kerja, yaitu prinsip kegiatan ekstrakurikuler yang membangun semangat peserta didik untuk bekerja dengan baik dan berhasil

f. Kemanfaatan sosial, yaitu prinsip kegiatan ekstrakurikuler dilaksanakan untuk kepentingan masyarakat.

Secara garis besar kegiatan ekstrakurikuler mempunyai 3 (tiga) tujuan dasar sebagai berikut :

a. Pembinaan Minat dan Bakat Siswa

Kegiatan ekstrakurikuler diharapkan dapat membina dan mengembangkan minat yang ada pada siswa serta memupuk bakat yang dimiliki siswa

b. Sebagai Wadah di Sekolah

Dengan aktifnya siswa dalam kegiatan ekstrakurikuler, secara otomatis siswa telah membentuk wadah-wadah kecil yang di dalamnya akan terjalin komunikasi antar anggotanya dan sekaligus dapat belajar dalam mengorganisir setiap aktivitas kegiatan ekstrakurikuler

c. Pencapaian Prestasi yang Optimal

Beberapa cabang ekstrakurikuler baik secara perseorangan maupun kelompok diharapkan dapat meraih prestasi yang optimal, baik di lingkungan sekolah maupun di luar sekolah.

Fungsi dari kegiatan ekstrakurikuler adalah sebagai berikut :

a. Pengembangan yaitu fungsi kegiatan ekstrakurikuler untuk mengembangkan kemampuan dan kreativitas peserta didik sesuai dengan potensi, bakat, dan minat mereka

b. Sosial yaitu fungsi kegiatan ekstrakurikuler untuk mengembangkan kemampuan dan rasa tanggung jawab sosial peserta didik

c. Rekreaktif yaitu fungsi kegiatan ekstrakurikuler untuk mengembangkan suasana rileks, menggembirakan, dan menyenangkan bagi peserta didik yang menunjang proses perkembangan 
d. Persiapan karir yaitu fungsi kegiatan ekstrakurikuler untuk mengembangkan kesiapan karir peserta didik.

Kegiatan ekstrakurikuler dilakukan dalam format-format sebagai berikut :
a. Individual, yaitu format kegiatan ekstrakurikuler yang diikuti peserta didik secara perseorangan
b. Kelompok, yaitu format kegiatan ekstrakurikuler yang diikuti oleh kelompok-kelompok peserta didik
c. Klasikal, yaitu format kegiatan ekstrakurikuler yang diikuti peserta didik dalam satu kelas

d. Gabungan, yaitu format kegiatan ekstrakurikuler yang diikuti peserta didik antarkelas/antarsekolah
e. Lapangan, yaitu format kegiatan ekstrakurikuler yang diikuti seseorang atau sejumlah peserta didik melalui kegiatan di luar kelas atau kegiatan lapangan.

\section{Karakter}

Karakter adalah sesuatu yang sangat penting dan vital bagi tercapainya tujuan hidup. Karakter merupakan dorongan pilihan untuk menentukan yang terbaik dalam hidup. Pendidikan karakter pada dasarnya dibentuk oleh beberapa pilar yang saling berkaitan. Adapun pilar-pilar karakter ini adalah nilainilai luhur yang terdiri dari :

1. Trustworthiness (bentuk karakter yang membuat seseorang menjadi berintegritas, jujur, dan loyal)

2. Fairness (bentuk karakter yang membuat seseorang memiliki pemikiran terbuka serta tidak suka memanfaatkan orang lain)

3. Carring (bentuk karakter yang membuat seseorang memiliki sikap peduli dan perhatian terhadap orang lain maupun kondisi sosial lingkungan sekitar)

4. Respect (bentuk karakter yang membuat seseorang selalu menghargai dan menghormati orang lain)

5. Citizenship (bentuk karakter yang membuat seseorang sadar hukum dan peraturan serta peduli terhadap lingkungan alam)
6. Responsibility (bentuk karakter yang membuat seseorang bertanggung jawab, disiplin, dan selalu melakukan sesuatu dengan sebaik mungkin)

\section{Kegiatan Ekstrakurikuler Membentuk Karakter}

Berbagai upaya strategis yang harus dilakukan oleh generasi muda dalam menghadapi nilai-nilai budaya bangsa adalah sebuah koordinasi gerakan revitalisasi kebangsaan yang diarahkan terutama pada penguatan ketehanan masyarakat dan bangsa terhadap segenap upaya nihilisasi dari pihak luar terhadap nilai-nilai budaya bangsa. Sebagai pedoman pengembangan karakter peserta didik melalui kegiatan ekstrakurikuler yang merupakan bagian dari pembinaan kesiswaan di sekolah.

Dalam ekstrakurikuler selain mengasah kemampuan dan bakat serta dapat mengembangkan sikap sportif, jujur, disiplin, cinta tanah air, menghargai prestasi, kerja sama, dan bertanggung jawab maka dapat membantu pengembangan karakter, memperkenalkan akan nilai-nilai semangat tim, serta mengajarkan untuk rendah hati dalam kemenangan dan optimis dalam kekalahan. Pengembangan nilai/karakter dibagi dalam empat pilar, yaitu kegiatan pembelajaran di kelas, kegiatan keseharian dalam bentuk budaya sekolah (school culture), kegiatan kokurikuler atau ekstrakurikuler, serta kegiatan keseharian di rumah, dan di masyarakat.

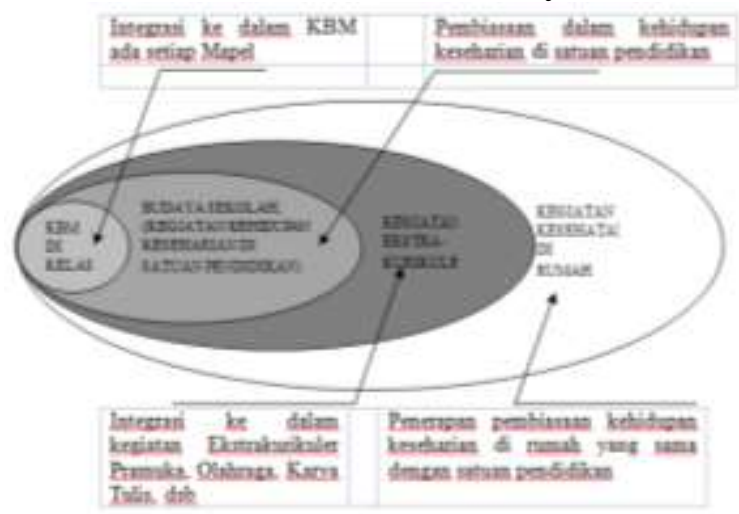

Sumber : Samani dan Hariyanto (2012:113) Gambar 1. Konteks Pendidikan Karakter 


\section{METODELOGI PENELITIAN}

Jenis penelitian ini adalah penelitian deskriptif, Best (dalam Sukardi, 2003:157) mengemukakan bahwa "penelitian deskriptif merupakan metode penelitian yang berusaha menggambarkan dan menginterpretasikan objek sesuai dengan apa adanya". Penelitian ini juga sering disebut noneksperimen, karena pada penelitian ini peneliti tidak melakukan kontrol dan memanipulasi variabel penelitian. Menurut West (dalam buku Sukardi, 2003:157), “dengan metode deskriptif, peneliti memungkinkan untuk melakukan hubungan antarvariabel, menguji hipotesis, mengembangkan generalisasi, dan mengembangkan teori yang memiliki validitas universal". Penelitian deskriptif pada umumnya dilakukan dengan tujuan umum, yaitu menggambarkan secara sistematis fakta dan karakteristik objek ataupun subjek yang diteliti secara tepat.

\section{HASIL DAN PEMBAHASAN}

Setelah melakukan penelitian di SMA Negeri 1 Brandan Barat diperoleh data siswa pada setiap butir soal angket karakter siswa pada kegiatan ekstrakurikuler diperoleh data, melalui data-data tersebut langkah selanjutnya adalah mendeskripsikan data dengan cara menghitung persentase butir soal angket kemudian disesuaikan dengan kategori yang ditentukan.

Tabel 1. Frekuensi dan Rekapitulasi dari Setiap Indikator

\begin{tabular}{|c|c|c|c|c|c|c|}
\hline \multirow{2}{*}{ No. } & \multirow{2}{*}{ Indikator } & \multicolumn{2}{|c|}{$\begin{array}{c}\text { Jumlah } \\
\text { Butir Soal }\end{array}$} & \multicolumn{3}{|c|}{ Skor } \\
\hline & & + & - & $\begin{array}{c}\text { Ment } \\
\text { ah }\end{array}$ & $\%$ & $\begin{array}{l}\text { Sehar } \\
\text { usnya }\end{array}$ \\
\hline 1. & Trustworthiness & 445 & 367 & 812 & 84,58 & 960 \\
\hline 2. & Fairness & 494 & 437 & 931 & 96,98 & 960 \\
\hline 3. & Carring & 417 & 401 & 818 & 85,20 & 960 \\
\hline 4. & Respect & 313 & 494 & 807 & 84,06 & 960 \\
\hline 5. & Citizenship & 393 & 367 & 760 & 79,17 & 960 \\
\hline 6. & Responsibility & 418 & 284 & 702 & 83,57 & 840 \\
\hline & $\sum$ & 2480 & 2350 & 4830 & & \\
\hline
\end{tabular}

Berdasarkan hasil penelitian dan analisis data diperolehsetiap indikator pada angket karakter siswa di SMA Negeri 1 Brandan Barat diperoleh Trustworthiness sebesar 84,58 \% kategori tinggi, Fairness sebesar 96,98\% kategori sangat tinggi, Carringsebesar 85,20\% kategori sangat tinggi, Respectsebesar 84,06\% kategori tinggi, Citizenship sebesar $79,17 \%$ kategori tinggi, Responsibility sebesar 83,57 \% kategori tinggi. Dapat disimpulkan bahwa indikator untuk angket karakter siswa yang mengikuti ekstrakurikuler sangat baik. Hal ini membuktikan bahwa kegiatan ekstrakurikuler memberikan dampak positif terhadap karakter siswa SMA Negeri 1 Brandan Barat dilihat dari persentase keseluruhan termasuk dalam kategori sangat tinggi.

Abstraksi yang tampak di sekolah SMA Negeri 1 Brandan Barat sesuai dengan ke-enam pilar karakter seperti trustworthiness (Siswa memiliki wawasan yang luas, Siswa memiliki semangat belajar yang tinggi, Seluruh siswa mengasah kemampuan dan bakat yang dimiliki), fairness (Siswa memiliki kelompok belajar, Siswa aktif dalam organisasi disekolah baik itu OSIS, Rohis (Organisasi Keagamaan), PMR), carring (Rasa simpati dan empati siswa yang tinggi seperti saat ada orangtua dari teman mereka yang meninggal mereka memberikan sumbangsih moril dan materil, Siswa bahumembahu dalam menciptakan suasana sekolah yang nyaman, bersih dan asri), respect (Siswa sangat menghormati guru, Siswa sangat menghargai orang lain selain warga sekolah seperti halnya peneliti saat meneliti sekolah tersebut), citizenship (Siswa tidak terlambat datang ke sekolah, Siswa berpakaian rapi dengan tidak mengeluarkan baju seragam sekolah, Siswa memakai attribute sekolah, Siswa memarkirkan kendaraan (sepeda motor) sesuai pada tempatnya), dan responsibillity (Saat praktek di lapangan bertanggung jawab atas sarana dan prasarana yang dipergunakan, Siswa membuang sampah pada tempatnya).

Table 2. Kategori Persentase Kegiatan Ekstrakurikuler Siswa Kumulatif

\begin{tabular}{clcc}
\hline NO & KATEGORI & $\begin{array}{c}\text { JUMLAH } \\
\text { SISWA }\end{array}$ & $\begin{array}{c}\text { KATEGORI } \\
\text { PERSENTASE } \\
\text { SISWA }\end{array}$ \\
\hline 1 & Sangat Baik & 9 & 30 \\
\hline 2 & Baik & 19 & 63,33 \\
\hline 3 & Cukup & 2 & 6,67 \\
\hline 4 & Kurang & 0 & 0 \\
\hline
\end{tabular}


Dari data tabel diatas kategori persentase kegiatan ekstrakurikuler terhadap karakter siswa diperoleh, siswa dengan kategori sangat baik berjumlah 9 siswa, siswa dengan kategori berjumlah 19 siswa, siswa dengan kategori cukup berjumlah 2 orang, dan siswa dengan kategori kurang berjumlah 0 siswa. Dari tabel di atas dapat dibuat diagram lingkar, yakni :

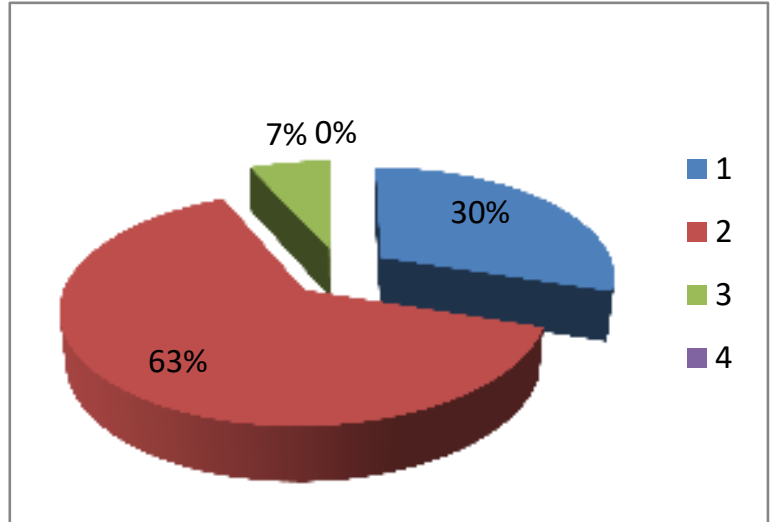

Gambar 2. Diagram Klasifikasi Persentase Karakter Siswa

Dari diagram diatas klasifikasi persentasi karakter siswa secara keseluruhan dapat dikatakan dengan kategori baik. Hal itu dikarenakan sebanyak $63,33 \%$ siswa memperoleh kategori baik.

\section{KESIMPULAN}

Berdasarkan analisa data pada Bab IV, maka hasil penelitian ini dapat disimpulkan bahwa : pada indikator trustworthiness sebesar 84,58 \% kategori baik, fairness sebesar 96,98\% kategori sangat baik, carring sebesar 85,20\% kategori sangat baik, respect sebesar 84,06\% kategori baik, citizenship sebesar $79,17 \%$ kategori baik, responsibility sebesar 83,57\% kategori baik. Dapat disimpulkan bahwa setiap indikator untuk angket karakter siswa yang mengikuti ekstrakurikuler sangat baik. Hal ini memberikan dampak positif yang signifikan pada karakter siswa yang mengikuti ekstrakurikuler di SMA Negeri 1 Brandan Barat bahwa pada kegiatan ekstrakurikuler yang diikuti siswa akan membentuk karakter siswa SMA Negeri 1 Brandan Barat dilihat dari rata-rata persentase keseluruhan termasuk dalam kategori sangat tinggi.

\section{DAFTAR PUSTAKA}

Ahmadi, Abu. dan Supriyono. Widodo. (2008). Psikologi Belajar. Penerbit : Rineka Cipta. Jakarta.

Budiningsih, Asri. C,. (2008). Pembelajaran Moral. Penerbit : Rineka Cipta. Jakarta.

Depdikbud. (1998). Petunjuk Pelaksanaan Kegiatan Ekstrakurikuler Sebagai Salah Satu Jalur Pembinaan Kesiswaan. Departemen Pendidikan dan Kebudayaan : Dirjend Dikdasmen. Jakarta.

Hartasasmita. (1985). Strategi Pengembangan Masyarakat dan Pedoman Merancang Sistem Kursus dan Latihan. Bandung FIP IKIP Bandung.

Koesoema A., Doni. (2010). Pendidikan Karakter. Penerbit : Grasindo. Jakarta.

Moekijat. (2002). Motivasi dalam Pembelajaran. Jakarta : Mulia.

Muslich, Masnur. (2011). Pendidikan Karakter $\begin{array}{llll}\text { Menjawab } & \text { Tantangan } & & \text { Krisis } \\ \text { Multidemsional. } & \text { Penerbit : PT } & \text { Bumi } \\ \text { Aksara. Jakarta. } & & & \end{array}$

Nazir, Moh. (2003). Metode Penelitian. Penerbit : Ghalia Indonesian. Jakarta.

Samani, Muchlas. dan Hariyanto. (2012). Konsep dan Model Pendidikan Karakter. Penerbit : PT Remaja Rosdakarya. Jakarta.

Saputri, L. (2018). Pengaruh Pendekatan Realistic Mathematics Education (RME) Terhadap Kemampuan Penalaran Matematika Siswa SMKS-PP Stabat. Jurnal MATEMATICS PAEDAGOGIC. Vol II. No. 2, Maret 2018, hlm. 180 - 187.

Saputri, L. (2020). Peningkatan Self Confidence Mahasiswa Prodi Prndidikan Matematika Melalui Model Pembelajaran 
Kooperatif Tipe Jigsaw Di STKIP

Budidaya. Jurnal Serunai Ilmu Pendidikan Vol.6, No.1, Juni 2020. 